Egyptian Journal of Aquatic Biology \& Fisheries

Zoology Department, Faculty of Science,

Ain Shams University, Cairo, Egypt.

ISSN $1110-6131$

Vol. 24(2): $19-38$ (2020)

www.ejabf.journals.ekb.eg

\title{
Impact of the water quality of El-Rahawy Drain on some genetic and histopathological aspects of Oreochromis niloticus
}

\author{
Medhat H. Hashem ${ }^{1}$, Safaa I. Tayel ${ }^{2}$, Ebrahim A. Sabra ${ }^{1}$, Amal M. Yacoub², \\ Anas A. Heiba*1
}

1. Genetic Engineering and Biotechnology Research Institute, University of Sadat city, Egypt.

2. National Institute of Oceanography and Fisheries, Cairo, Egypt.

*Corresponding Author: anas-heaba@hotmail.com

ARTICLE INFO

Article History:

Received: Feb.28, 2020

Accepted: March 22, 2020

Online: March 15, 2020

Keywords:

River Nile,

Rosetta Branch,

water quality,

heavy metals,

Orechromus niloticus,

Inter-simple sequence

repeats (ISSR)

\section{ABSTRACT}

The present study aims to evaluate the water quality of two locations in Rosetta Branch of River Nile and its histopathological and genetic adverse effects on Nile tilapia (Oreochromis niloticus). Water and fish samples were collected from up and downstream of El-Rahawy Drain discharge point (location I and II, respectively) during the summer and winter seasons. The water quality, liver histopathology and DNA alteration of fish was examined. ISSR-PCR technique was used to assess the genetic variation of fish samples from these locations. The water quality parameters ( BOD, COD,..... )were increased at location II compared with location I in addition to depletion in dissolved oxygen. Moreover, the fish samples collected from location II showed severe histological and molecular alterations than those collected from location I. It is recommended that the government must increase the awareness of people around the River Nile, and improve the environmental management to reduce the risks of polluted water and consuming the fish exposed to this water on human health.

\section{INTRODUCTION}

The River Nile is the donor of life to Egypt and represents the principle freshwater resource that meets nearly all demands for drinking water and irrigation (Korium and Toufeek, 2008 and Ali et al., 2008). River Nile water quality has been steadily deteriorating over several decades due to the dumping of anthropogenic inputs and untreated effluents. The Nile runs through a narrow valley (1000 km long). Subsequently, it is bifurcate at a distance of $25 \mathrm{~km}$ (north of Cairo) into the Rosetta and Damietta branches forming a delta (Abdel-Satar et al., 2017). Rosetta Branch passes cutting six governorates; El-Kalubia, El-Menofiya, El-Giza, El-Gharbia, Kafr ElShiekh and El-Boheira 'over a length of about $236 \mathrm{~km}$ on the western boundary of the Nile Delta from Egypt's Delta Barrage with an average width of $180 \mathrm{~m}$ and depth from 2 to $4 \mathrm{~m}$ (El Gammal and El Shazely, 2008). 
There are three main sources of pollution which potentially affect and deteriorate the water quality of Rosetta Branch, El-Rahawy Drain that receives all sewage of El-Giza governorate in addition to agricultural and domestic wastes of El-Rahway village and discharge these wastes directly without treatment into the branch (Tayel et al., 2008).

Pollutants include heavy metals can cause an imbalance between the free radical species production and reduction in fish (Livingstone, 2003; Sevcikova et al., 2011; Kamollerd $\boldsymbol{e t}$ al., 2019). The free radicals can attack lipid, protein and DNA molecules to induce oxidative stress products as well as cause DNA damage (Castano and Becerril, 2004; Vilela et al., 2018; Kamollerd et al., 2019).

For the estimation of metal pollution concentrations, fishes can be considered as one of the most significant biomonitors in the aquatic system (Begum, 2004). As a sequence, $O$. niloticus is the most common freshwater fish used in toxicological studies. They are considered an important food source of protein in Africa and some areas of the world (Figueiredo-Fernandes et al., 2006; Ahmed, 2007 and Mahmoud and El Naggar, 2007).

To study the adverse effects of pollution, histopathological and DNA molecular markers have been used. The histopathological study is referring to any adverse effect on fish (Bayomy and Mahmoud, 2007 and Ahmed et al., 2019). It allows examining specific target organs, that are responsible for vital functions, such as producing antibody against blood born antigens, excretion, the accumulation and biotransformation of xenobiotics in the fish (Thophon et al., 2003; Tayel et al., 2008 and El-Naggar et al., 2009).

On the other hand, inter-simple sequence repeats ISSR analysis by using PCR has been successfully applied in fish gene tagging, genetic diversity analysis and pollutants effects studies (Archak et al., 2003). Also, the analysis was widely used for studying the genetic background of fish (Liu et al., 2006, Rashed et al., 2008 and Saad et al., 2009). ISSR has proven to be outstanding in the analysis of natural population vertebrate species (Priyanka et al., 2013).

So, the present study aims to evaluate the water quality of two locations in Rosetta Branch of River Nile and its histopathological and genetic adverse effects (by using ISSR markers) on Nile tilapia Oreochromis niloticus.

\section{MATERIALS AND METHODS}

\section{Study area}

The River Nile enters Egypt at its southern boundary with Sudan and runs through a narrow valley (1000 km long). Subsequently, it is bifurcate at a distance of 25 $\mathrm{km}$ (north of Cairo) into the Rosetta and Damietta branches forming a delta (AbdelSatar et al., 2017). This study is focused on the two locations, upstream (location I) and downstream (location II) of El-Rahawy Drain discharge point in the River Nile at Rosetta Branch, where the drainage water shows its influence on the branch. Rosetta 
River Nile Branch represents the main freshwater stream that extends northwards for about $225 \mathrm{~km}$ on the western boundary of the Nile Delta. Fig. 1 shows the study area of Rosetta Branch. Rosetta Branch receives daily huge quantities of polluted waters from many sources including agricultural, industrial in addition to urban sewage containing high amount of organic and inorganic wastes that are causing serious negative impacts on the branch environment (Abdel-Satar and Elewa, 2001).

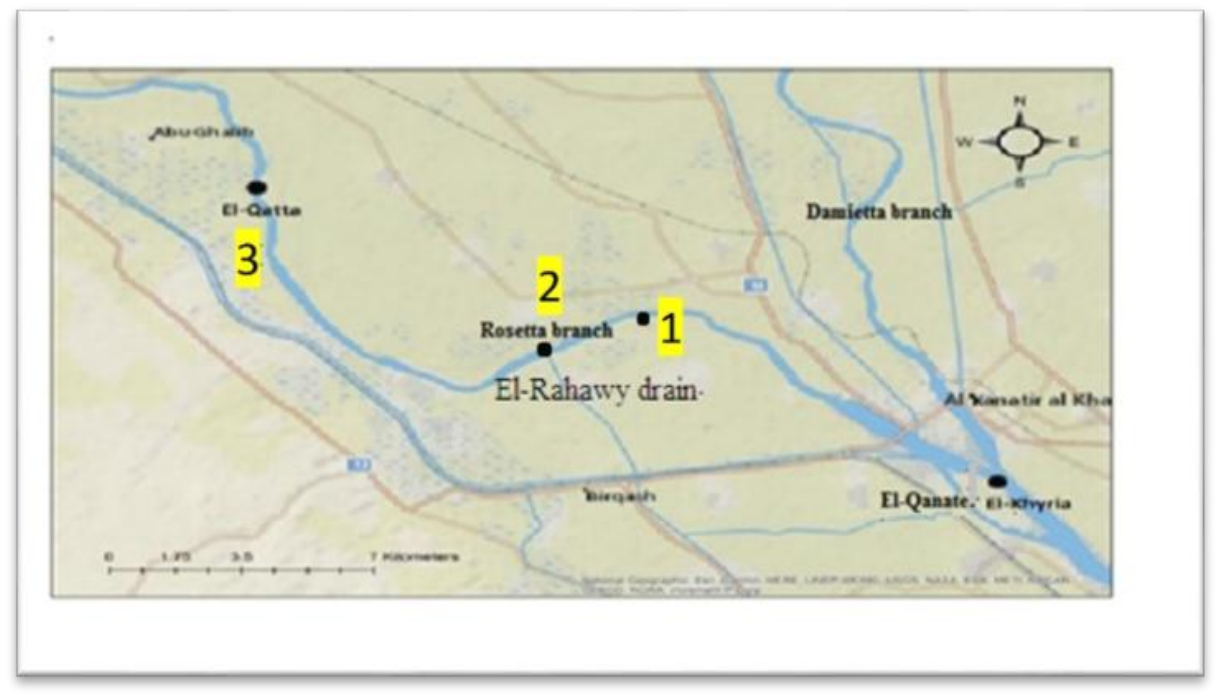

Fig. (1): A map of of El-Rahawy Drain, showing the sampling locations, 1: Upstream location before $1 \mathrm{~km}$ from the drain (location I), 2: discharge point 3: Downstream location after $5 \mathrm{~km}$ from the drain (location II).

\section{Water Sampling}

Water samples were collected during the winter and summer seasons from the two locations (upstream and downstream the discharge point of El-Rahawy drain).

\section{Water analysis}

The water temperature was measured by a dry mercury thermometer. The electrical conductivity $\left(\mathrm{mScm}^{-1}\right)$ was estimated using conductivity meter model (S.C.T.33 YSI) and transparency $(\mathrm{cm})$ was recorded in the field using Secchi-disc (diameter $25 \mathrm{~cm}$ ). $\mathrm{pH}$ was measured on the spot by using pH-meter (model Janway 3150).

Another water samples were kept in one-liter polyethylene bottle in ice box to be analyzed in the laboratory. Concentrations of studied parameters were determined according to the procedures laid down in APHA (1995). The dissolved oxygen (DO) content was performed by azide modification, biological oxygen demand (BOD) by incubation 5 days methods and chemical oxygen demand (COD) by using potassium permanganate. Concentrations of nitrite, nitrate and ammonia, were determined using the colorimetric techniques with formation of reddish purple azo-dye, $\mathrm{Cd}$ reduction and phenate methods, respectively.

Water samples for metals determination were kept in clean stoppered plastic bottles and preserved with $65 \% \mathrm{HNO}_{3}$ to $\mathrm{pH}<2$ in the field. After that the water 
samples were digested using $65 \% \mathrm{HNO}_{3}$ according to APHA (1995). Analysis of heavy metals concentrations ( $\mathrm{Fe}, \mathrm{Zn}, \mathrm{Mn}, \mathrm{Pb}$ and $\mathrm{Cu}$ ) was carried out by using atomic absorption spectrophotometer model (Perkin Elmer 3110 USA) with graphite atomizer HGA-600, according to the method described by APHA (1995) and the reading was compared with a standard curve. All determinations were performed in duplicate and were repeated when added accuracy was needed. The relationships between different studied variables in Nile water were calculated using the Pearson correlation index

\section{Histopathological studies:}

Liver samples obtained from $O$. niloticus were carefully removed then fixed in $10 \%$ formalin, dehydrated in ascending grades of alcohol and cleared in xylene. The fixed tissues were embedded in paraffin wax and sectioned at 5 microns by using Euromex Holland microtome. Sections were stained according to Harris Hematoxylin and Eosin method (Bernet $\boldsymbol{e t}$ al., 1999), examined microscopically and photographed by using a microscopic camera.

\section{ISSR markers}

\section{DNA extraction}

Fish muscles tissues were used for DNA extraction through genomic DNA extraction kit (G-Spin) from iNtRON Biotechnology, Inc., Korea. DNA extraction of 20 fish samples from the two locations (10 samples from each, 5 males and 5 females) was carried out as described in the manufacturer's protocol.

\section{PCR amplification conditions}

Five ISSR markers loci were screened. The ISSR primers sequences are presented in Table '. PCR conditions were 5 mins at $94^{\circ} \mathrm{C}$ followed by $60 \mathrm{sec}$ at $94^{\circ} \mathrm{C}, 45 \mathrm{sec}$ at 50 ${ }^{\circ} \mathrm{C}$ and $60 \mathrm{Sec}$ at $72{ }^{\circ} \mathrm{C}$ for 35 cycles and a final step for $10 \mathrm{mins}$ at $72{ }^{\circ} \mathrm{C}$. PCR products were tested by using $2 \%$ agarose gel electrophoresis. 100 bp DNA ladder plus (iNtRON Biotechnology, Inc. Korea) was used to detect the obtained PCR products. The electrophoresis run was achieved at $75 \mathrm{~V}$ in DNA electrophoresis unit (Bio-Rad) for 90 mins.

Table (1): Sequences of ISSR primers

\begin{tabular}{cc}
\hline Primer & Primer Sequence $\left(\mathbf{5}^{\prime}-\mathbf{3}^{\prime} \mathbf{)}\right.$ \\
\hline $\mathbf{1}$ & AGA GAG AGA GAG AGA G \\
\hline $\mathbf{2}$ & GAG AGA GAG AGA GAG AT \\
\hline $\mathbf{4}$ & GAG AGA GAG AGA GAG AC \\
\hline $\mathbf{5}$ & CTC TCT CTC TCT CTC TG \\
\hline
\end{tabular}

\section{RESULTS AND DISCUSSION}

Physico-chemical characteristics of Sub-surface water samples along the studied locations of River Nile are recorded in Table (2). 
Table (2): Physico-chemical seasonal variations of River Nile water

\begin{tabular}{|c|c|c|c|c|c|c|}
\hline \multirow{3}{*}{ Parameter } & \multicolumn{4}{|c|}{ Season } & \multirow[b]{3}{*}{ Mean } & \multirow{3}{*}{$\begin{array}{c}\text { CCME } \\
(2007)\end{array}$} \\
\hline & \multicolumn{2}{|c|}{ Summer } & \multicolumn{2}{|c|}{ Winter } & & \\
\hline & Location I & Location II & Location I & Location II & & \\
\hline Temperature $\left({ }^{\circ} \mathrm{C}\right)$ & 26.4 & 28.2 & 16 & 17.4 & 22 & - \\
\hline Transparency $(\mathbf{c m})$ & 112.5 & 50.5 & 76 & 30 & 67.25 & - \\
\hline $\mathrm{EC}(\mu \mathrm{S} / \mathrm{cm})$ & 263 & 532.7 & 418.7 & 870 & 521.1 & - \\
\hline PH & 7.4 & 7.5 & 7.94 & 7.04 & 7.47 & $6.5-9$ \\
\hline DO mg/l & 7.2 & 1.2 & 6.6 & 0.8 & 3.95 & $5.5-9.5$ \\
\hline BOD mg/l & 3.6 & 46.4 & 2.5 & 61.6 & 28.53 & - \\
\hline COD mg/l & 14.7 & 35.35 & 9.7 & 16.55 & 19.08 & - \\
\hline Ammonia mg/ l & 0.22 & 7.03 & 0.14 & 13.3 & 5.17 & $0.19-0.47^{*}$ \\
\hline Nitrite $\mu \mathrm{g} / \mathrm{l}$ & 8.45 & 17.1 & 11.1 & 45.15 & 20.45 & 60 \\
\hline Nitrate $\mu \mathrm{g} / \mathrm{l}$ & 23.1 & 29.35 & 45.65 & 56.1 & 38.55 & 2900 \\
\hline
\end{tabular}

*NH3 concentration depend on $\mathrm{pH}$ value

\section{Water temperature}

Temperature is an important factor in the aquatic environment since it affects directly or indirectly not only on the survival and distribution of the aquatic organisms at any stage of life, but also on their growth rate, development, activity, activation of reproduction processes and susceptibility to diseases (Moustafa et al., 2010 and Abdo et al., 2010). In the present study, water temperature showed noticeable seasonal trends with the lowest value $\left(16^{\circ} \mathrm{C}\right)$ recorded during winter at location (I) and the highest value $\left(28.2^{\circ} \mathrm{C}\right)$ during summer at location (II). The changes in water temperature may depend on the variations in meteorological conditions, air temperature, latent heat of evaporation and different sampling times and seasons (Saad et al., 2011 and Ahmed, 2012). On the other hand, bacteria and other microorganisms that affect the breakdown of organic matter at El-Rahawy Drain are very much influenced by temperature changes. Consequently, they are more active during summer than winter. This observation was agreed with that reported by Mahmoud and El-Naggar (2007) and Tayel et al. (2008).

\section{Transparency}

Transparency means the penetration of the light into water layers. It is controlled by depth and turbidity of the water and affected by particulate contents of water from suspended matter and floating substances (Mahmoud et al., 2008). In the present study, the transparency values fluctuated between $112.5 \mathrm{~cm}$ recorded at location (I) during the summer season and $30 \mathrm{~cm}$ recorded at location (II) during the winter season. The obtained result showed a remarkable decrease in transparency values at location (II) which was attributed to the discharge of heavily polluted effluent loaded with domestic, industrial, and agriculture wastes (Saad $\boldsymbol{e t}$ al., 2011). Also, the decrease in transparency during winter was attributed to the effect of the prevailing wind which helps in mixing water and stirring up the bottom sediments (Ahmed, 2012). On the other hand, the high values of transparency may be attributed to the increase in the uptake of 
suspended matter by phytoplankton and increased solar radiation penetrating the surface water as well as for settling out of suspended particles to the bottom sediments especially during summer (Abdel-Satar and Elewa 2001; Abdel-Satar, 2005 and Saad et al., 2011).

\section{Electrical conductivity (EC)}

Electrical conductivity is a measure of the ability of an aqueous solution to carry an electric current. This ability depends on the presence of ions, their total concentration, mobility, valance, and temperature of the medium. The more abundant of the ions in aqueous solution lead to increase the electrical conductivity and vice versa (APHA, 1995). The obtained data showed that the lowest value of EC (263 $\mu \mathrm{S} / \mathrm{cm}$ ) measured at location (I) during the summer season may be attributed to the increase of water level during flood period and the uptake of dissolved salts by phytoplankton (Ghallab, 2000 and Saad et al., 2011). On the other hand, the increase in EC $(1160.2 \mu \mathrm{S} / \mathrm{cm})$ at location (II) during winter may be attributed to the intrusion of the drain's effluent into the lowered level water in the branch causing elevation of dissolved and suspended particles which increase the ability to convey electrical current (El-Sayed, 2011 and Ahmed, 2012). Generally, the high values of EC may be attributed to domestic and agricultural wastes that contain a high amount of organic and inorganic constituents (Al-Afify and Abdel-Satar, 2020).

\section{Hydrogen ion concentration (pH)}

Measurement of $\mathrm{pH}$ is one of the most important and frequently used tests in water chemistry. Practically, every phase of water supply and wastewater temperature, e.g. acid-base neutralization, water softening, precipitation, coagulation, disinfection and corrosion control is $\mathrm{pH}$-dependent (Abdel-Satar, 2005). The principle system regulating the $\mathrm{pH}$ of water is the carbonate system which includes $\mathrm{CO}_{2}, \mathrm{H}_{2} \mathrm{CO}_{3}, \mathrm{HCO}_{3}{ }^{-}$and $\mathrm{CO}_{3}{ }^{2-}$ . The $\mathrm{pH}$ value of water is controlled by dissolved oxygen, algal photosynthetic activity, temperature, sewage discharge, decomposition of organic matter and complex factors related to the geology of the under-laying sediment (Tayel, 2003).

The obtained values of $\mathrm{pH}$ were on the alkaline side (7.04-7.94). The increase in $\mathrm{pH}$ values at location (I) in the winter season may be attributed to the dense vegetation and phytoplankton, which were accompanied by photosynthetic activity and consumption of $\mathrm{CO}_{2}$ with expected pH elevation (Sabae, 2004 and Abdel- Satar, 2005). On the other hand, the relative decrease of $\mathrm{pH}$ values at location (II) in the same season may be attributed to lower activities of phytoplankton as well as to bacterial and fungal action in the sediment; these activities liberate methane and hydrogen sulphide that lead to the formation of organic acids (Ahmed, 2012)

\section{Dissolved Oxygen (DO)}

Dissolved oxygen is considered as an important parameter in the assessment of the degree of pollution in natural water (Mahmoud et al., 2008). There are many factors affect the amount of oxygen in natural water such as temperature, salinity, amount of mixing between air and water, $\mathrm{pH}$, photosynthetic activity of phytoplankton, 
submerged plant, and aeration by living organisms as well as decomposition of organic matter (Das and Acharya, 2003).

In the present study, dissolved oxygen values varied from $6.6 \mathrm{mg} / \mathrm{l}$ to $7.2 \mathrm{mg} / \mathrm{l}$ at location (I) and $0.8 \mathrm{mg} / \mathrm{l}$ to $1.2 \mathrm{mg} / \mathrm{l}$ at location (II), respectively (Fig. 2). Downstream the decrease of DO was recorded, where the domestic wastes discharged contains a high load of the organic pollutants that consume the dissolved oxygen during oxidation processes (Mahmoud $\boldsymbol{e t}$ al., 2008, Abdo et al., 2010 and Ahmed, 2012). On the other hand, the increase of DO at location (I) may be due to the high solubility of oxygen at low water temperature, the activities of wind action and air movement which allow more transfer of oxygen across the airwater interface as well as the increase of photosynthetic activity by phytoplankton (Mahmoud $e t \quad a l ., 2008 \quad$ and Saad $e t \quad a l ., 2011)$. Finally, DO concentrations at site II were lower than the CCME (2007) threshold limits established to protect water quality for aquatic life, Table 2 .

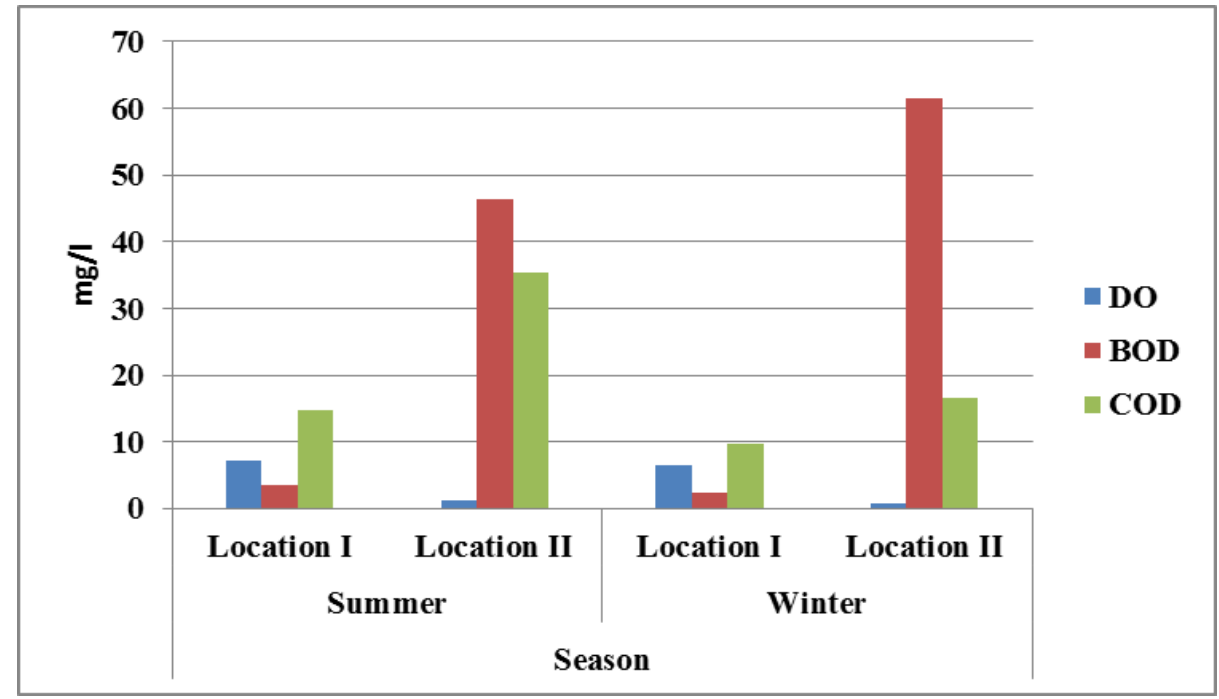

Fig. (2): The variation of DO, BOD and COD in the River Nile at Rosetta Branch water

\section{Biological Oxygen Demand (BOD)}

The BOD is the amount of DO consumed to decompose the organic matter in water by microorganisms. It depends on several factors such as temperature, the concentration of organic matter and the density of phytoplankton. The BOD test is the mostly useful method in estimating the amount of biodegradable organic matter present in the aquatic environment (El-Sayed, 2011).

The obtained results showed a remarkable increase in biological oxygen demand values downstream of untreated wastes (sewage, agriculture, domestic) discharged from El-Rahawy Drain to Rosetta Branch that reach to the maximum value $(61.6 \mathrm{mg} / \mathrm{l})$ during winter season (Fig. 2); this may be attributed to decomposition of a high amount of organic matter by microorganisms. These results are in agreement with that obtained by Al-Afify (2010) and El-Sayed (2011). While the minimum value $(2.5 \mathrm{mg} / \mathrm{l})$ was 
recorded at location (I) which may be attributed to low photosynthetic activity and no abundance of phytoplankton at this area (Ahmed, 2007).

\section{Chemical Oxygen Demand (COD)}

The chemical oxygen demand is the total amount of oxygen required to oxidize all the organic matter completely to $\mathrm{H}_{2} \mathrm{O}$ and $\mathrm{CO}_{2}$ (Sincero and Sincero, 2003). The high values of COD that recorded at location (II), (Fig. 2) may be due to the effect of pollution by sewage and agriculture wastes discharged from El-Rahawy Drain as well as the high load of organic matter and the low capacity of its water for self-purification (AbdelSatar, 2005; Abdo, 2010; Saad et al., 2011). Also, the increase in COD value during summer season could be attributed to the increase in water temperature which accelerates the oxidation of organic matter (Abdo, 2010). As classified by Saad et al. (2011), the water to be of good quality when it contains not more than $12 \mathrm{mg} / \mathrm{l}$ of organic matter expressed as oxygen consumed by permanganate. On the other hand, the reduction of COD in the present study at location I may be due to the algal biomass which is capable of consuming organic material as recorded by Ghallab (2000).

\section{Ammonia $\left(\mathrm{NH}_{3}-\mathrm{N}\right)$}

Ammonia and nitrogen concentrations more than $1 \mathrm{mg} / \mathrm{l}$ have been given as an indicator of organic pollution and can be toxic to aquatic species if they are higher than $2.5 \mathrm{mg} / \mathrm{l}$ (Ahmed, 2012). In the present study, the values of ammonia ranged from $0.14 \mathrm{mg} / \mathrm{l}$ to $0.22 \mathrm{mg} / \mathrm{l}$ at location (I) and $7.03 \mathrm{mg} / \mathrm{l}$ to $13.3 \mathrm{mg} / \mathrm{l}$ at location (II), Table (2). The increase of ammonia values at location (II) during all seasons may be due to a large amount of organic matter outfalls and their decomposition of the organic matter exhausting dissolved oxygen and produce a high level of ammonia (Abdel-Satar, 2005 and Saad et al., 2011). Also, the increase of ammonia concentration may be attributed to the activity of denitrifying bacteria which are much higher under anaerobic conditions as mentioned by Gallab, (2000). On the other hand, the decrease in the ammonia concentrations was related to the decrease in biological activities of aquatic organisms and nitrification in the water column as investigated at location (I) (Saad $\boldsymbol{e}$ t al., 2011). The present results declared that ammonia levels in water samples at location II were exceeded the CCME (2007) guidelines for the protection of aquatic life, Table 2. Nitrite $\left(\mathrm{NO}_{2}^{-}-\mathrm{N}\right)$

Nitrite is an intermediate oxidation state of nitrogen, both in the oxidation of ammonia to nitrate and in the reduction of nitrate, such oxidation and reduction occur in natural water. Resistance to toxic effect of nitrite ion is enhanced by the presence of chloride or increased water hardness (APHA, 1995).

The values of nitrite ranged between 8.45 and $11.1 \mu \mathrm{g} / \mathrm{l}$ at location (I) during summer season while, the values fluctuated from 17.1 to $45.15 \mu \mathrm{g} / 1$ at location (II) during the winter season, Fig. 3. The low values of nitrite might be attributed to the fast conversion of $\mathrm{NO}_{2}^{-}$by nitrobacteria to $\mathrm{NO}_{3}^{-}$(Abdo, 2004 and Tayel, 2007). On the other hand, the high nitrite level may be attributed to the decomposition of organic matter 
present in the wastewater where nitrosomonas bacteria oxidize ammonia to nitrite (Saad et al., 2011).

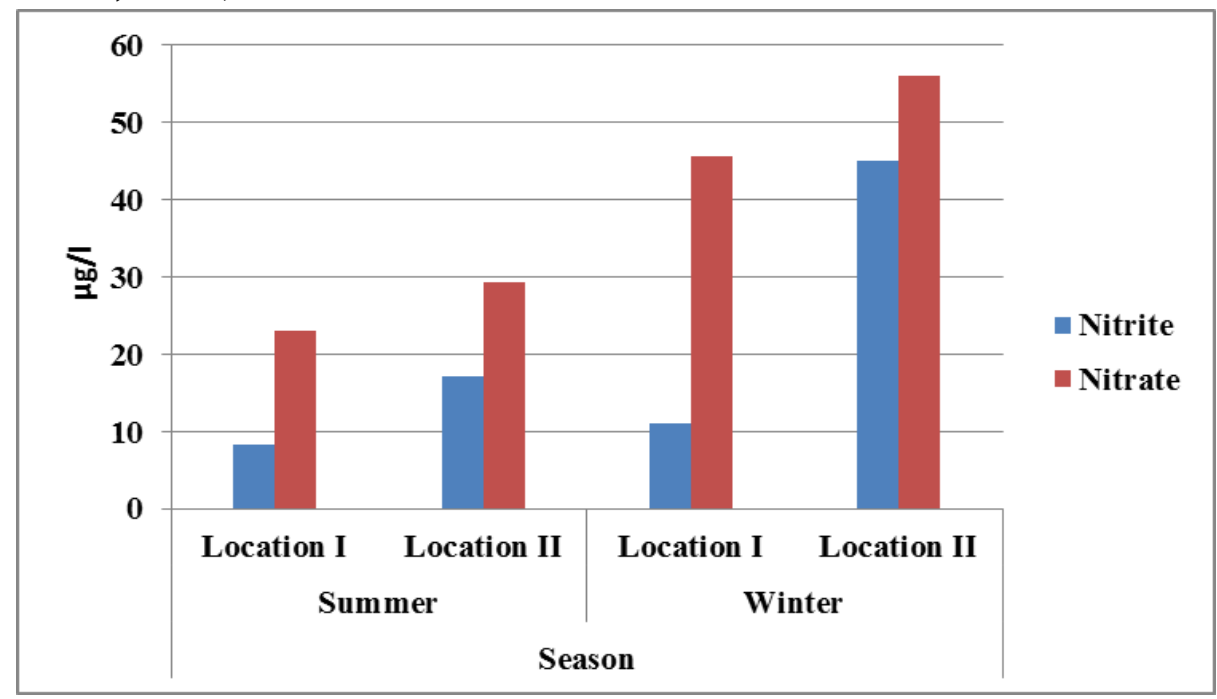

Fig. (3): The variation of nitrite and nitrate levels in the River Nile at Rosetta Branch water

\section{Nitrate $\left(\mathrm{NO}_{3}{ }^{-}-\mathrm{N}\right)$}

The reduction of nitrate can be brought about by certain nitrate reducing bacteria especially in the presence of organic matter and only limited amounts of oxygen (AbdelSatar, 2005). This happens, for instances in heavily polluted, streams and in sewage percolating filters that have become pended or clogged (Bayomy and Mahmoud, 2007). During denitrification, nitrate was reduced to nitrite and finally to ammonia, under certain circumstances nitrous oxidation $\left(\mathrm{NO}_{2}^{-}\right)$and nitrogen are also produced (Abdel-Satar $\boldsymbol{e t}$ al., 2017).

The values of nitrate fluctuated within a wide range between 23.1 and $56.1 \mathrm{mg} / \mathrm{l}$, Fig. 3. The low values of nitrate might be attributed to the uptake of nitrate by natural phytoplankton and its reduction by denitrifying bacteria and biological denitrification (Sabae and Abdel- Satar, 2001; Bayomy and Mahmoud, 2007 and Saad et al., 2011). On the other hand, the increase of nitrate levels might be attributed to sewage wastes at El-Rahawy Drain and low consumption of phytoplankton as well as the oxidation of ammonia by nitrosomonas bacteria and biological nitrification (Abdo, 2010 and Saad et al., 2011).

\section{Heavy metals}

The average concentrations of heavy metals in Nile water were in the decreasing order of: $\mathrm{Fe}>\mathrm{Zn}>\mathrm{Mn}>\mathrm{Cu}>\mathrm{Pb}$. The High levels of all studied metals were recorded at location II during different seasons reflecting the overwhelming influence of wastewater on metals distribution in the Nile water, Table 3. Statistically, Fe, Mn, Pb and $\mathrm{Cu}$ concentrations shows negative correlations with $\mathrm{pH}(\mathrm{r}=(-0.65)-(-0.76), \mathrm{n}=4, \mathrm{p}$ $<0.01$ ), during summer and winter seasons, which suggest that, the $\mathrm{pH}$ have been acclaimed to responsible for mobilization of heavy metals in Rosetta Branch (Abdel- 
Satar and Elewa 2001). Also, the levels of $\mathrm{Fe} \mathrm{Zn}, \mathrm{Pb}$ and $\mathrm{Cu}$ often surpassed the CCME (2007) guidelines for aquatic-life. These elevated concentrations are almost certainly a result of anthropogenic sources (Abdel-Satar et al., 2017). The significant correlations $(\mathrm{r}=0.5-0.99 ; \mathrm{n}=4, \mathrm{p}<0.01)$ among heavy metals pairs indicated common sources and association of metals (Abdel-Satar, 2005).

Table (3): Seasonal variations of heavy metals concentrations (mg/l) in the River Nile water

\begin{tabular}{|c|c|c|c|c|c|}
\hline \multirow[b]{3}{*}{ Parameter } & \multicolumn{4}{|c|}{ Seasons } & \multirow{3}{*}{$\begin{array}{c}\text { CCME } \\
(2007)\end{array}$} \\
\hline & \multicolumn{2}{|c|}{ Summer } & \multicolumn{2}{|c|}{ Winter } & \\
\hline & Location I & Location II & Location I & Location II & \\
\hline $\mathbf{F e}$ & 0.140 & $\mathbf{0 . 7 2 0}$ & 0.250 & 0.940 & 0.3 \\
\hline Zn & 0.085 & 0.154 & 0.098 & 0.112 & 0.03 \\
\hline Mn & 0.025 & 0.085 & 0.032 & 0.150 & - \\
\hline $\mathbf{P b}$ & 0.022 & 0.041 & 0.025 & 0.058 & 0.002 \\
\hline $\mathrm{Cu}$ & 0.012 & 0.034 & 0.015 & 0.045 & 0.002 \\
\hline
\end{tabular}

\section{Histopathological studies}

Histopathology is used as a sub-lethal test for evaluating toxic effect of water pollutants on fish (Tayel et al., 2020). The liver is the principal organ of detoxification in vertebrates and particularly in fish. The normal structure of the liver shows that, it is made up of hepatocytes which arranged in the branched lamina. They are polygonal cells with a central spherical nucleus that separated from each other by blood sinusoids. Blood flows from branches of the hepatic portal vein and hepatic artery through the sinusoids to central veins which empty into the hepatic vein (Fayed, 2004).

The liver of $O$. niloticus fish collected from upstream (A\&C) and downstream (B\&D) locations (Fig. 4), suffered from many pathological alterations. These alterations were necrosis, and fatty degeneration in hepatocytes as well as the blood vessel showed congestion, destruction in its wall. Severe hemorrhage was accompanied and congestion in blood sinusoids. These findings were in agreement with those reported by (Yacoub and Abdel-Satar, 2003; Ibrahim and Mahmoud, 2005; El- Naggar et al., 2009 and Saad et al., 2011, Ismail et al., 2017; Tayel et al., 2018). The fatty degeneration changes in studied liver may be due to the decrease in the rate of utilization of energy reserve or pathological enhance synthesis while the abnormal accumulation of fats in an experimental animal could be due to induced imbalance between fat production and utilization (El-Naggar $\boldsymbol{e t}$ al., 2009 and Tayel $\boldsymbol{e t}$ al., 2018). The same investigation was regarded by (Tayel, 2003) on the tilapia fish. As a sequence, the fish collected from location (II) showed more histopathological alteration than those collected from location (I); this may be attributed to heavy metals accumulation (Sitohy et al., 2006; Ibrahim, 2007 and Yacoub et al., 2008), parasitic infection (Mahmoud and El-Naggar, 2007 and El-Naggar et al., 2009) and changes in water quality (Abu-Elala $\boldsymbol{e t}$ al. (2016), Bayomy et al., 2017 and Ahmed et al., 2019). 

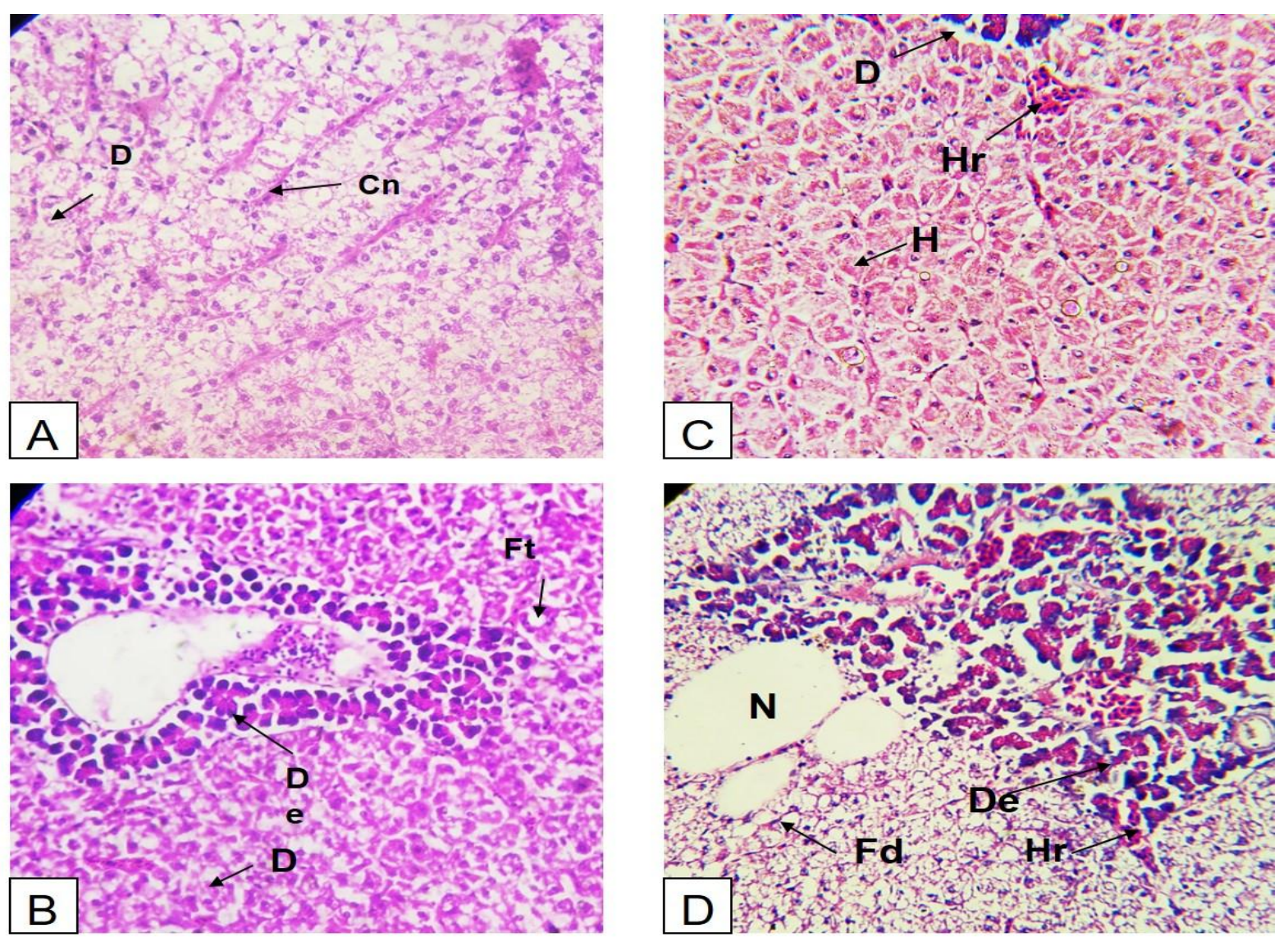

Fig. (4): Liver sections of $O$ niloticus collected from up and downstream locations of El-Rahawy Drain discharge point at Rosetta Branch (formalin 10-H\&E) showing:

a) Congestion (Cn) in blood sinusoid and Degeneration (D) in hepatocytes.

b) Fatty degeneration (Fd), Degeneration (D) in hepatocytes and Destruction (De) in blood vessel

c) Degeneration (D) in blood vessel Hemorrhages (Hr) and hepatocytes appear normal shape (H)

d) Necrotic area $(\mathrm{N})$, Degeneration (D) \& fatty degeneration (Fd) in hepatocytes and Destruction (De) in blood vessel.

\section{ISSR markers}

Pollutants include heavy metals can cause an imbalance between the free radical species production and reduction in fish (Livingstone, 2003; Sevcikova et al., 2011; Kamollerd et al., 2019). The free radicals can attack lipid, protein and DNA molecules to induce oxidative stress products as well as cause DNA damage (Castano and Becerril, 2004; Vilela et al., 2018; Kamollerd et al., 2019). Genetic markers such as ISSR markers are vital tools for monitoring fish populations (Rashed $\boldsymbol{e t}$ al., 2008) and fish species genetic variability (Saad et al., 2009).

In the present study, five primers of ISSR were used to study the effects of water pollution on tilapia nilotica fish from the two locations. The DNA fragments generated by the five primers of ISSR (P1-P5) were separated using 2\% agarose gel electrophoresis and are shown in Fig. 5. 


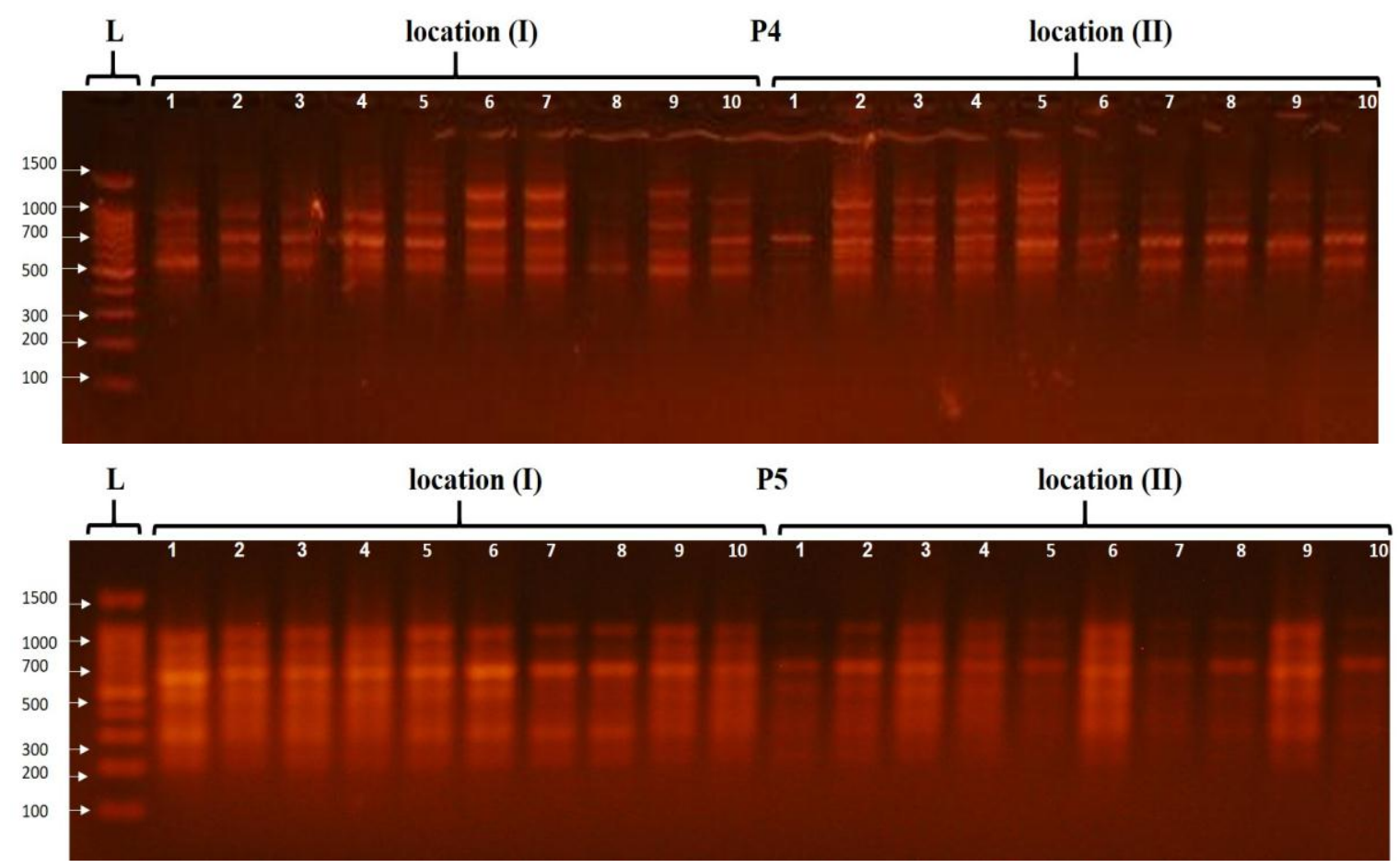

Fig. (5): Examples of Agarose gel electrophoresis for amplified ISSR fragments using P4 and P5 primers with samples of the two different locations. Lines 1-5: males, Lines 6-10: Female and L: DNA ladder.

A total of 29 reproducible fragments were obtained for each sex samples with the used primers. Tables 4 and 5 displayed the obtaining fragments that were scored as 1 or 0 (appearance/disappearance, respectively). The ISSR results of different samples from the two locations were compared based on the sex (males or females) to eliminate any effects of the sex. The five ISSR primers produced 3 - 10 fragments with an average of 5.8 fragments per primer. The highest number of fragments was obtained with P1, while P3 gave the lowest number. The obtained fragments were primer dependent and were in the size range of 300 to $2000 \mathrm{bp}$. As observed from Table 4, in males' samples, there were a number of 6 unique fragments (1 with P1, 2 with P3 and 4 with P4) between the two locations, while 8 unique fragments were obtained in females' samples (2 with each P1 and P2, 3 with P3 and 1 with P4), Table 5.

These unique fragments indicate to mutation occurrence. Compared with location I samples; five mutations were occurred in the template DNA of location II samples at DNA sites that previously were complementary to the primer. So, the fragments were not produced as fragments 2 and 3 with P3 and 5 and 9 with P4 in males while in females, there was only one produced fragment (fragment 2 with P3). While, eight mutations were induced in sites were not previously complementary to the primer and new fragments were produced such as fragments 4 and 6 with P4 in males and 4 and 5 with P1, 1 and 2 with P2 and 4 and 10 with P4 in females' samples. 
Table (4): The obtained fragments and 0/1 table of the five ISSR primers that were used with males' samples from the two locations.

\begin{tabular}{|c|c|c|c|c|c|c|c|c|c|c|c|}
\hline \multirow[b]{3}{*}{ Primer } & \multirow[b]{3}{*}{ Band } & \multicolumn{10}{|c|}{ Male samples } \\
\hline & & \multicolumn{5}{|c|}{ Location (I) } & \multicolumn{5}{|c|}{ Location (II) } \\
\hline & & Male1 & Male2 & Male3 & Male4 & Male5 & Male1 & Male2 & Male3 & Male4 & Male5 \\
\hline \multirow{6}{*}{ P1 } & 1 & 1 & 1 & 1 & 1 & 1 & 1 & 1 & 1 & 1 & 1 \\
\hline & 2 & 1 & 1 & 1 & 1 & 1 & 0 & 0 & 0 & 1 & 1 \\
\hline & 3 & 1 & 1 & 1 & 1 & 1 & 0 & 0 & 1 & 1 & 1 \\
\hline & 4 & 1 & 1 & 1 & 1 & 1 & 1 & 1 & 1 & 1 & 1 \\
\hline & 5 & 1 & 1 & 1 & 1 & 1 & 1 & 1 & 1 & 1 & 1 \\
\hline & 6 & 1 & 1 & 1 & 1 & 1 & 1 & 1 & 1 & 1 & 1 \\
\hline \multirow{4}{*}{ P2 } & 1 & 1 & 1 & 1 & 1 & 1 & 1 & 1 & 1 & 1 & 1 \\
\hline & 2 & 1 & 1 & 1 & 1 & 1 & 1 & 1 & 1 & 1 & 1 \\
\hline & 3 & 1 & 1 & 1 & 1 & 1 & 1 & 1 & 1 & 1 & 1 \\
\hline & 4 & 1 & 1 & 1 & 1 & 1 & 1 & 1 & 1 & 1 & 1 \\
\hline \multirow{3}{*}{$\mathbf{P 3}$} & 1 & 1 & 1 & 1 & 1 & 1 & 1 & 1 & 1 & 1 & 1 \\
\hline & 2 & 1 & 1 & 1 & 1 & 1 & 0 & 0 & 0 & 0 & 0 \\
\hline & 3 & 1 & 1 & 1 & 1 & 1 & 0 & 0 & 0 & 0 & 0 \\
\hline \multirow{10}{*}{ P4 } & 1 & 0 & 1 & 1 & 1 & 1 & 1 & 0 & 0 & 1 & 1 \\
\hline & 2 & 0 & 1 & 1 & 1 & 1 & 1 & 1 & 1 & 1 & 1 \\
\hline & 3 & 0 & 1 & 1 & 1 & 1 & 0 & 1 & 1 & 1 & 1 \\
\hline & 4 & 0 & 0 & 0 & 0 & 0 & 1 & 1 & 1 & 1 & 1 \\
\hline & 5 & 1 & 1 & 1 & 1 & 1 & 0 & 0 & 0 & 0 & 0 \\
\hline & 6 & 0 & 0 & 0 & 0 & 0 & 0 & 1 & 1 & 1 & 1 \\
\hline & 7 & 1 & 1 & 1 & 1 & 1 & 0 & 1 & 1 & 1 & 1 \\
\hline & 8 & 1 & 1 & 1 & 1 & 1 & 1 & 1 & 1 & 1 & 1 \\
\hline & 9 & 1 & 1 & 1 & 1 & 1 & 0 & 0 & 0 & 0 & 0 \\
\hline & 10 & 1 & 1 & 1 & 1 & 1 & 1 & 1 & 1 & 1 & 1 \\
\hline \multirow{6}{*}{ P5 } & 1 & 1 & 1 & 1 & 1 & 1 & 1 & 1 & 1 & 1 & 1 \\
\hline & 2 & 1 & 1 & 1 & 1 & 1 & 1 & 1 & 1 & 1 & 1 \\
\hline & 3 & 1 & 1 & 1 & 1 & 1 & 1 & 1 & 1 & 1 & 1 \\
\hline & 4 & 1 & 1 & 1 & 1 & 1 & 1 & 1 & 1 & 1 & 1 \\
\hline & 5 & 1 & 1 & 1 & 1 & 1 & 1 & 1 & 1 & 1 & 1 \\
\hline & 6 & 1 & 1 & 1 & 1 & 1 & 1 & 1 & 1 & 1 & 1 \\
\hline
\end{tabular}

In addition, in males, fragment number 3 that was obtained with P1 was disappearance in males 1 and 2 of location II samples. As well as, fragment 3 produced with P1 was not exhibited in females 3, 4 and 5 of location II samples compare with other samples. This indicates that, the mutations occurred in some individuals only.

On the other hand, the dendrogram of males and females' samples were shown in Figs. 6 and 7, respectively. The dendrogram separated the studied samples into two clusters corresponding to studied location. The location I samples were in a separated cluster from those samples of location II in the two sexes. 
Table (5): The obtained fragments and 0/1 table of the five ISSR primers that were used with females' samples from the two locations.

\begin{tabular}{|c|c|c|c|c|c|c|c|c|c|c|c|}
\hline \multirow[b]{3}{*}{ Primer } & \multirow[b]{3}{*}{ Band } & \multicolumn{10}{|c|}{ Female samples } \\
\hline & & \multicolumn{5}{|c|}{ Location (I) } & \multicolumn{5}{|c|}{ Location (II) } \\
\hline & & Female1 & Female2 & Female3 & Female4 & Female5 & Female1 & Female2 & Female3 & Female4 & Female5 \\
\hline \multirow{6}{*}{ P1 } & 1 & 1 & 0 & 0 & 1 & 1 & 1 & 1 & 0 & 0 & 1 \\
\hline & 2 & 0 & 0 & 1 & 1 & 0 & 1 & 1 & 0 & 1 & 1 \\
\hline & 3 & 1 & 1 & 1 & 1 & 1 & 1 & 1 & 0 & 0 & 0 \\
\hline & 4 & 0 & 0 & 0 & 0 & 0 & 1 & 1 & 1 & 1 & 1 \\
\hline & 5 & 0 & 0 & 0 & 0 & 0 & 1 & 1 & 1 & 1 & 1 \\
\hline & 6 & 1 & 1 & 1 & 1 & 1 & 1 & 1 & 1 & 1 & 1 \\
\hline \multirow{6}{*}{$\mathbf{P 2}$} & 1 & 0 & 0 & 0 & 0 & 0 & 1 & 1 & 1 & 1 & 1 \\
\hline & 2 & 0 & 0 & 0 & 0 & 0 & 1 & 1 & 1 & 1 & 1 \\
\hline & 3 & 1 & 1 & 1 & 1 & 1 & 1 & 1 & 1 & 1 & 1 \\
\hline & 4 & 1 & 1 & 1 & 1 & 1 & 1 & 1 & 1 & 1 & 1 \\
\hline & 5 & 1 & 1 & 1 & 1 & 1 & 1 & 1 & 1 & 1 & 1 \\
\hline & 6 & 1 & 1 & 1 & 1 & 1 & 1 & 1 & 1 & 1 & 1 \\
\hline \multirow{4}{*}{$\mathbf{P 3}$} & 1 & 0 & 1 & 0 & 0 & 0 & 0 & 0 & 0 & 0 & 0 \\
\hline & 2 & 1 & 1 & 1 & 1 & 1 & 0 & 0 & 0 & 0 & 0 \\
\hline & 3 & 1 & 1 & 1 & 1 & 1 & 0 & 0 & 1 & 1 & 0 \\
\hline & 4 & 0 & 0 & 0 & 0 & 0 & 0 & 0 & 0 & 0 & 1 \\
\hline \multirow{10}{*}{ P4 } & 1 & 0 & 1 & 0 & 0 & 0 & 0 & 0 & 0 & 0 & 0 \\
\hline & 2 & 1 & 1 & 0 & 0 & 0 & 1 & 0 & 0 & 0 & 0 \\
\hline & 3 & 0 & 1 & 0 & 1 & 0 & 1 & 0 & 0 & 0 & 0 \\
\hline & 4 & 1 & 0 & 1 & 0 & 0 & 0 & 0 & 0 & 0 & 0 \\
\hline & 5 & 0 & 1 & 0 & 0 & 0 & 0 & 0 & 0 & 0 & 0 \\
\hline & 6 & 1 & 0 & 0 & 1 & 1 & 1 & 1 & 1 & 1 & 1 \\
\hline & 7 & 1 & 1 & 1 & 0 & 1 & 1 & 1 & 1 & 1 & 1 \\
\hline & 8 & 1 & 0 & 1 & 1 & 1 & 1 & 0 & 0 & 1 & 0 \\
\hline & 9 & 1 & 0 & 1 & 1 & 1 & 1 & 1 & 1 & 1 & 1 \\
\hline & 10 & 0 & 0 & 0 & 0 & 0 & 0 & 1 & 1 & 1 & 1 \\
\hline \multirow{6}{*}{ P5 } & 1 & 1 & 1 & 1 & 1 & 1 & 1 & 1 & 1 & 1 & 1 \\
\hline & 2 & 1 & 1 & 1 & 1 & 1 & 1 & 1 & 1 & 1 & 1 \\
\hline & 3 & 1 & 1 & 1 & 1 & 1 & 1 & 1 & 1 & 1 & 1 \\
\hline & 4 & 1 & 1 & 1 & 1 & 1 & 1 & 1 & 1 & 1 & 1 \\
\hline & 5 & 1 & 1 & 1 & 1 & 1 & 1 & 1 & 1 & 1 & 1 \\
\hline & 6 & 1 & 1 & 1 & 1 & 1 & 1 & 1 & 1 & 1 & 1 \\
\hline
\end{tabular}

The genetic variations in fish samples from the same sex in different locations indicated a positive correlation with metals concentrations in the water. These results suggested that the heavy metals accumulation in the water causes DNA damage. These finding support the study of Kamollerd et al. (2019). Wood et al., 2001; Monserrat et al., 2007; Vilela et al., 2018 reported that, in the polluted water, heavy metal exposure could cause DNA damage in fish as double and strand single breakages, alterations in the mechanism of DNA repair and DNA-protein crosslinks. Heavy metals can induce 
oxidative stress, DNA damage, point mutations and several other indirect genotoxic effects (Waalkes, 2003; Castano and Becerril, 2004; Suhartono et al., 2013 and Kamollerd et al., 2019).

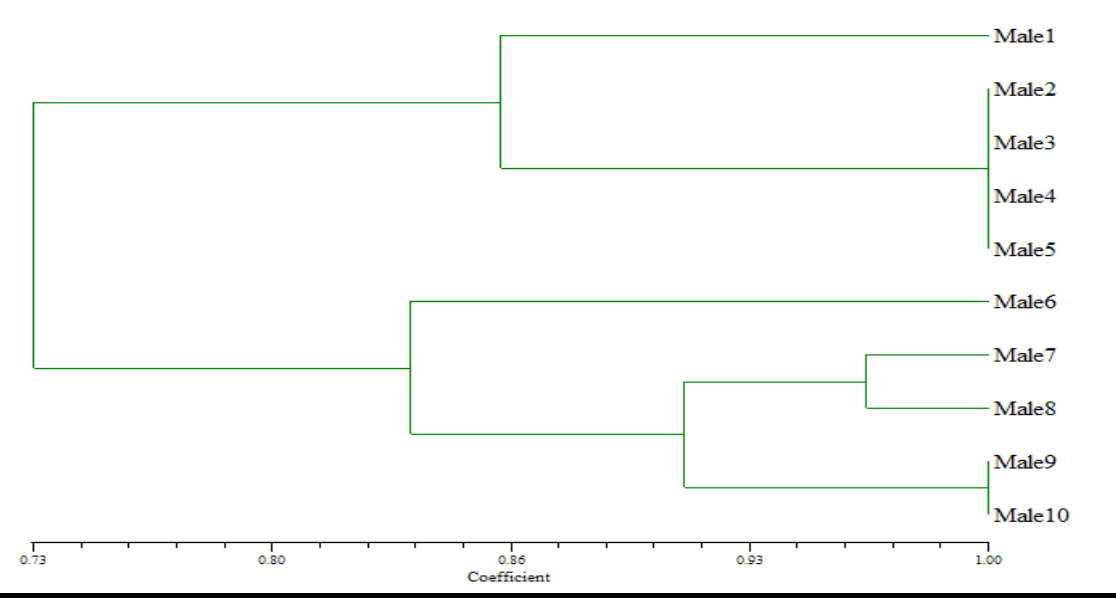

Fig. (6): The dendrogram constructed from five primers of ISSR showing the tilapia males samples genetic relationships from location I (Males 1-5) and location II (males 6-10).

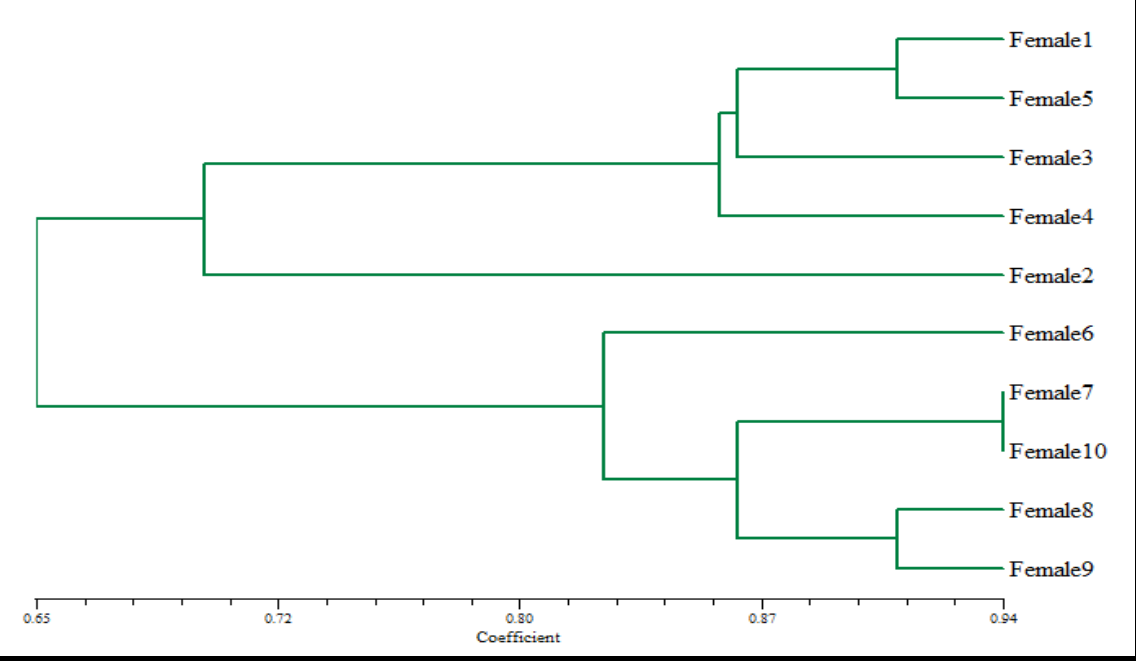

Fig. (7): The dendrogram constructed from the five primers of ISSR showing tilapia females samples genetic relationships from location I (females 1-5) and location II (females 6-10).

\section{CONCLUSION}

From the previous discussion, it can be concluded that, the water quality parameters were increased at location II in addition to depletion in dissolved oxygen. Also, the fish samples collected from this location showed severe histological and molecular alterations than those collected from location I. It is recommended that the government must increase the awareness of people around the River Nile, and improve the environmental management to reduce the risks of polluted water and consuming the fish exposed to this water on human health. 


\section{REFERENCES}

Abdel-Satar, A.M. (2005). Water quality assessment of River Nile from Idfo to Cairo. Egypt J. Aquatic Res., 31(2): 200 - 223.

Abdel-Satar, A.M. and Elewa, A.A. (2001). Water quality and environmental assessments of the River Nile at Rosetta branch. The second International conference and exhibition for life and environment, 136 - 164.

Abdel-Satar, A.M.; Ali, M.H.H and Goher, M.E. (2017). Indices of water quality and metal pollution of Nile River, Egypt. Egyptian J. of Aquatic Research, 43, 21-29.

Abdo, M.H. (2004) Seasonal variations of some heavy metals in macrophytes and water of Damietta Branch, River Nile, Egypt. Egypt. J. of Aquatic Biology and Fisheries, 8: $195-211$.

Abdo, M.H. (2010) Environmental and water quality evaluation of Damietta branch, River Nile, Egypt. African J. Biol. Sci., 6(2): 143-158.

Abdo, M.H.; Sabae, S.Z.; Haroon, B.M.; Refaat, B.M. and Mohammed, A.S. (2010). Physico-chemical characteristics, microbial assessment and antibiotic susceptibility of pathogenic bacteria of Ismailia Canal water, River Nile, Egypt. J. of Amer. Sci., 6(5): 234-250.

Abu-Elala, N.M.; Abd-Elsalam, R.M.; Marouf, S.; Abdelaziz, M. and Moustafa, M. (2016). Eutrophication, Ammonia Intoxication, and Infectious Diseases: Interdisciplinary Factors of Mass Mortalities in Cultured Nile Tilapia. Journal of Aquatic Animal Health, 145:187-198.

Ahmed, N.A.M. (2012). Biochemical studies on pollution of the River Nile at different stations of Delta barrage (Egypt). Ph.D. Thesis, fac. Agri., Benha Univ., Egypt

Ahmed, N.A.M.; Flefil, N.S.; Tayel, S.I.; Mahmoud, S.A. and Soliman, A. (2019). Biological treatment of ammonia using biofloc system for Oreochromis niloticus fish. Egyptian Journal of Aquatic Biology \& Fisheries Zoology Department, Faculty of Science, Ain Shams University, Cairo, Egypt.Vol. 23(4): 639 - 657

Al-Afify, A.D.G. (2010). Biochemical and ecological studies on El-serw fish farm. PhD. Thesis, Fac. of Agric. Cairo Univ., Egypt.

Al-Afify, A.D.G. and Abdel-Satar, A.M. (2020). Risk assessment of heavy metal pollution in water, sediment and plants in the Nile River in the Cairo region, Egypt. Oceanological and Hydrobiological Studies, 49(1):1-12.

Ali, S.M.; Sabae, S.Z.; Fayez, M. and Hegazi, N.A. (2008). Sugar and starch industries as a potential source of water pollution of the River Nile south of Cairo: Microbiological and chemical studies. J. Egypt. Academic Society for Environmental development, 9: 25-45.

APHA (1995). standard Methods for the Examination of water and waste, American public Health Association. New York, 1193. 
Archak S.; Gaikwad A.B.; Gautam D.; Rao E.V.V.B.; Swamy K.R.M.; and Karihaloo J.L. (2003). Comparative assessment of DNA fingerprinting techniques (RAPD, ISSR, and AFLP) for genetic analysis of cashew (Anacardium occidentale L.) accessions of India. Genome, 46: 362-369.

Bayomy, M.F.F. and Mahmoud, S.A. (2007). Some hematological and histological studies on Clarias gariepinus fish living in different location of the River Nile in relation to water quality criteria. J. Egypt. Ger. Soc. Zool., 54(c): 33-47.

Bayomy, M.F.F.; Elewa, A.A.; Tayel, S.I.; El-Kasheif, M.A. and El- Zeer M.E. (2017). Toxicological studies of water with a particular reference to its effect on Clarias gariepinus fish at El-Bahr El- Pharaony Drain, El-Menoufiya Governorate, Egypt. Journal of Bioscience and Applied Research, 3 (3): 265-272.

Begum, G. (2004). Cabofuran insecticide induced biochemical alterations in liver and muscle tissues of the fish Clarias batrachus (Linn.) and recovery response. Aquat. Toxicol., 66: 83-92.

Bernet, D.; Schmidt, H.; Meier, W.; Burkhardt-Olm, P. and Wahi, T. (1999). Histopathology in fish: Proposal for a protocol to assess aquatic pollution. J. fish Disease, 22: 25-34.

Castano, A. and Becerril, C. (2004). In vitro assessment of DNA damage after short and long-term exposure to benzo (a) pyrene using RAPD and the RTG-2 fish cell line.Mutation Research 552: 141-151.

CCME (Canadian Council of Ministers of the Environment). (2007). For the protection of aquatic life 2007. In: Canadian Environmental Quality Guidelines, 1999, Canadian Council of Ministers of the Environment, 1999, Winnipeg.

Das, J. and Acharya, B.C. (2003). Hydrology and assessment of lotic water quality in Cuttack city. India Water, Air and Soil Pollution, 150:163-175.

El Gammal, A.H. and El Shazely, S.H. (2008). Water quality management scenarios in Rosetta River Nile branch, Egypt. $12^{\text {th }}$ International Water Technology Conference, IWTC12, Alexandria, Egypt.

EL-Naggar, A.M.; Mahmoud, S.A. and Tayel, S.I. (2009). Bioaccumulation of some heavy metals and histopathological alterations in liver of Oreochromis niloticus in relation to water quality at different localities along the River Nile, Egypt. World J. Fish and Marine Sci., 1(2):105-114.

El-Sayed, S. (2011). Physicochemical studies on the impact of pollution up on the River Nile branches, Egypt. M.Sc. Thesis Faculty of Science, Benha University, Egypt.

Figueiredo-Fernandes, A.; Fontaínhas-Fernandes, A.; Monteiro, R.A.F.; Reis- Henriques, M.A. and Rocha, E. (2006). Effects of the fungicide mancozeb in the liver structure of Nile tilapia, Oreochromis niloticus. Assessment and quantification of induced cytological changes using qualitative histopathology and the stereological pointsampled intercept method. Bull. Environ. Contam.Toxicol., 76(2): 249-255. 
Ghallab, M.H. (2000). Some physical and chemical changes on the River Nile downstream of Delta barrage at El-Rahawy Drain. M.Sc. Thesis. Fac. Sci. Ain Shams Univ., Egypt.

Ibrahim, S.A. and Mahmoud, S.A. (2005). Effect of heavy metals accumulation on enzyme activity and histology in liver of some Nile fish in Egypt. J. Aquat. Biol. and Fish, 9 (1): 203-219.

Ibrahim, S.S. (2007). Histopathological changes in some body organs of Oreochromis niloticus due to heavy metals in water of Sabal drainage, El-Menoufia, governorate. J. Egypt. Acad. Soc. Environ. Develop., 8 (2): 117-126.

Ismail N.M.; Ali, S.E. and Mohamed I.K. (2017). Biochemical and histological biomarker approaches in the assessment of the water pollution in some lined and unlined watercourses of Egypt. International Journal of Fisheries and Aquatic Studies, 5(3): 288-296.

Kamollerd, C.; Senaphan, K.; Tengjaroenkul, B.; Monkheang, P. and Neeratanaphan, L. (2019). Oxidative stress and genetic differentiation in experimental tilapia fish exposed to heavy metals in a reservoir near a municipal landfill. Applied Ecology and Environmental Research 17(6):12893-12907.

Korium, M.A. and Toufeek, M.E.F. (2008). Studies of some physico-chemical characteristics of old Aswan Dam Reservoir and River Nile water at Aswan. Egypt. J. Aquat. Research, 34: 149-167.

Liu, Y.G.; Chena, S.L.; Lia, J. and Lib., B.F. (2006). Genetic diversity in three Japanese flounder (Paralichthys olivaceus) populations revealed by ISSR markers. Aquaculture, 255(1-4): 565-572

Livingstone, D. (2003). Oxidative stress in aquatic organism in relation to pollution and agriculture. - Revue de Medecine Veterinaire 154: 427-430.

Mahmoud, S.A and El-Naggar, A.M. (2007). Alterations in Clarias gariepinus caused by pollutants at El-Rahawy area, Rosetta branch, River Nile, Egypt. J. Egypt. Acad. Environ., Develop., 8(2): 61-70.

Mahmoud, S.A.; Tayel, S.I. and Yacoub, A.M. (2008). Histopathological changes in kidneys of the fish Tilapia zillii and Clarias gariepinus under the effect of several pollutants along the River Nile. J. of the Egyptian German Society of Zoology, 56(C): 219-246.

Moustafa, M.M.; Ali, M.H.H.; Abdel-Satar, A.M.; Mohamed, T.Y. and Madbouly, S.M. (2010). Water quality assessment of Rosetta and Damietta branchs, River Nile, Egypt. African J. Biol. Sci., 6(2): 127-142.

Priyanka, S.R.; Uppalapati, S.R.; Kingston, J.J.; Murali, H.S. and Batra, H.V. (2013). Development of ISSR-derived SCAR marker-targeted PCR for identification of Aspergillus section Flavi members. Lett Appl Microbiol10.1111/lam.12207. 
Rashed, M.A., Saad, Y.M., Ibrahim, M.M. and El-Seoudy, A.A. (2008). Geneticstructure of Natural Egyptian Oreochromis niloticus evaluated from dominant DNA markers. Global Veterinaria, 2(2): 87 - 91.

Saad, S.M.M.; El-Deeb, A.E.; Tayel, S.I. and Ahmed, N.A.M. (2011). Haematological and histopathological studies on Clarias gariepinus in relation to water quality along Rossetta branch, River Nile, Egypt. Egypt. J. Exp. Biol. (Zool.), 7(2): 223 - 233.

Saad, Y.M., Mansour, A.A. and EL-Nagar, A.M. (2009). Monitoring of genetic polymorphism in some tilapia species based on fin tissues isozyme distributions. World J. Zool.,4(1): 24 - 28.

Sabae, S.Z. (2004). Monitoring of microbial pollution in the River Nile and the impact of some Human activities on its waters, Proc. $3^{\text {rd }}$ Int. Conf. Biol. Sci. Fac. Sci. Tanta Univ., 3: 200-214.

Sabae, S.Z. and Abdel-Satar, A.M. (2001). Chemical and Bacteriological studies on ElSalam Canal, Egypt. J. Egypt. Acad. Soc. Environ. Develop., 2(1): 173-197.

Sevcikova, M.; Modra, H.; Slaninova, A. and Svobodova, Z. (2011). Metals as a cause of oxidative stress in fish: a review. Veterinarni Medicina, 56: 537-546.

Sincero, A.P. and Sincero, G.A. (2003). Physical-chemical treatment of water and wastewater. IWA Publishing, London, 832 p.

Suhartono, E.; Triawanti; Yunanto, A.; Firdaus, R.T. and Iskandar (2013). Chronic cadmium hepatooxidative in rats: treatment with haruan fish (Channa striata) extract. APCBEE Procedia 5: 441-445.

Tayel, S.I. (2003). Histopathological, biochemical and hematological studies on Tilapia zillii and Claries gariepinus in relation to water quality criteria at different localities in Delta Barrage. Ph. D. Thesis, Fac. Sci., Benha branch, Zagazig Univ.

Tayel, S.I. (2007). Histological and biochemical seasonal change of Oreochromis niloticus muscles in relation to water quality at Zefta and EL-Mansoura cities, Damietta branch ,River Nile, Egypt. J. Egypt. Acad. Soc. Environ. Develop., 8(2) : 81-92.

Tayel, S.I. (2008). Histological and biochemical seasonal changes of Oreochromis niloticus muscles in relation to water quality at Zefta and El-Mansoura Cities, Damietta branch River Nile, Egypt. J. Egypt. Acad. Soc. Environ. Develop., 8(2):8192.

Tayel, S.I., Mahmoud, S.A., Ahmed, N.A.M. and Abdel Rahman A.S.A. (2018). Pathological impacts of environmental toxins on Oreochromis niloticus fish inhabiting the water of Damietta branch of the River Nile, Egypt. Egyptian Journal of Aquatic Biology, 22 (5): 309- 321

Tayel, S.I.; Ahmed, M.N. and Ramadan, E.A. (2020). Histopathological alterations and parasitic infection in Oreochromis niloticus fish inhabiting the River Nile water. Egyptian Journal of Aquatic Biology \& Fisheries, 24(1): 233-247. 
Thophon, S.; Kruatrachue, M.; Upathan, E.S.; Pokethitiyook, P.; Sahaphong, S. and Jarikhuan, S. (2003). Histopathological alterations of white seabass, Lates calcarifer in acute and sub chronic cadmium exposure. Environmental Pollution, 121: 307-320.

Vilela, C.L.S.; Bassin, J.P. and Peixoto, R.S. (2018). Water contamination by endocrine disruptors: Impacts, microbiological aspects and trends for environmental protection. Environmental Pollution 235: 546-559.

Waalkes, M.P. (2003). Cadmium carcinogenesis. Mutation Research, 533: 107-120.

Wood, R.D.; Mitchell, M.; Srouros, J. and Lindahi, T. (2001). Human DNA repair genes. Science 291: 1284-1289.

Yacoub, A.M. and Abdel-Satar, A.M. (2003). Heavy metals accumulation and macronutrients in the livers of some fish species of Bardawil Lagoon and their histological changes. Egypt. J. Aquat. Biol. and Fish. 7(4): 403-422.

Yacoub, A.M.; Mahmoud, S.A. and Tayel, S.I. (2008). Health status of Oreochromis niloticus in fish farm irrigated with drainage water in El-Fayoum Province, Egypt. Egypt. J. Aquat. Res., 34(1): 161-175. 